\title{
Successful Management of Severe Peripheral Tissue Ischemia after Arterial Catheterization in Micro Preemies using Humidification \& Topical Nitroglycerin
}

\author{
Yea-Seul Han, Songyi Song, Tae-Jung Sung, and Jiyoung Chun \\ Department of Pediatrics, Kangnam Sacred Heart Hospital, Hallym University Medical Center, Seoul, Korea
}

\section{ABSTRACT}

Micro preemies usually undergo arterial catheterization for frequent blood pressure monitoring and blood sampling. Peripheral tissue injury associated arterial catheterization is a well-described morbidity observed in neonates. Despite the potential permanent disability associated with this complication, the currently available therapeutic options remain limited. We report a unique case of a preterm infant who developed severe tissue ischemia after arterial catheterization of the radial artery and was successfully treated using extensive humidification and topical nitroglycerin ointment application over an extended period (36 days) until complete clinical recovery.

Key Words: Catheterization, Humidity, Ischemia, Premature infants, Nitroglycerin
동맥 카테터 삽입은 초극소 미숙아 및 중증 질환을 가진 신생아의 혈 역학적 감시 및 혈액검사 를 위해 신생아 중환자실에서 흔히 시행되는 침습적인 시술 방법으로, 비교적 합병증 발생이 적 은 요골동맥, 후경골동맥에 주로 삽입한다 ${ }^{1)}$. 그러나 드물지만 동맥 카테터 삽입으로 인해 이차 적으로 혈종, 혈전색전증, 혈관경련수축, 관류장애에 따른 조직허혈이나 말초신경의 손상, 정맥 염 등과 같은 합병증이 발생할 수 있으며, 적절한 치료를 받지 못할 경우 급속하게 괴사로 진행 되어 영구적인 손상을 남길 수 있다 ${ }^{2,3}$. 특히 초극소 미숙아의 경우 혈관 지름이 카테터 사이즈와 비교하여 상대적으로 작기 때문에 위와 같은 합병증에 더욱 취약하며, 합병증 발생시 심각한 후 유증을 남길 가능성이 높다 ${ }^{4)}$.

동맥 카테터 삽입으로 인한 조직 허혈의 표준치료는 원인이 되는 카테터를 즉시 제거하고 반 대편에 따뜻한 물이나 수건으로 온찜질을 하여 반사적 혈관확장을 유도하면서 심장의 위치보다 병변 부위를 높게 유지하는 것이다. 만약 증상이 지속된다면 항응고제나 혈전용해제, 수술적 치 료를 고려해 볼 수 있다). 그러나 아직 신생아 환자를 대상으로 한 임상연구가 부족하며 사용 가 능한 약제의 제한 및 적절한 치료지침 역시 확립되어 있지 않아 치료에 어려움이 있당.

저자들은 극소 저체중 출생아에서 우측 요골동맥 카테터 삽입 직후 일시적인 혈관경련수축 (vasospasm)으로 인해 조직 허혈 및 괴사가 발생하였으나 국소적인 nitroglycerin 연고 도포와 집
Received: 7 August 2017

Revised: 18 September 2017

Accepted: 28 September 2017

Correspondence to: Jiyoung Chun

Department of Pediatrics, Kangnam

Sacred Heart Hospital, Hallym

University Medical Center, 948-1

Daerim-dong, Yeingdunpo-gu,

Seoul 07441, Korea

Tel: +82-2-829-5142

Fax: +82-2-849-4469

E-mail: jiyoung2010@hallym.or.kr

Copyright(c)

By Korean Society of Neonatology.

All right reserved.

This is an Open-Access article distributed under the terms of the Creative Commons Attribution Non-Commercial License (http://creativecommons.org/licenses/ by-nc/4.0), which permits unrestricted non-commercial use, distribution, and reproduction in any medium, provided the original work is properly cited. 
중가습치료로 효과적으로 치료된 증례를 경험하여 문헌고찰과 함께 본 증례의 치료 경험을 보고하고자 한다.

\section{증례}

환자는 본원에서 재태 $24^{+2}$ 주 출생체중 $760 \mathrm{~g}$ 으로 제왕절개를 통 해 출생하였고, 산모는 35세 경산모로 특이병력 없었으며, 환자의 가족력 상 출혈 경향은 없었다. 아프가 점수는 1 분 2점, 5 분 4 점, 10 분 6점이었으며, 분만장에서 신생아 호흡 곤란 증후군에 대한 예방 적 치료로 기관 내 삽관 시행 후 인공 계면활성제를 투여한 뒤 신생 아중환자실로 입원하였다. 입실 직 후 인공 호흡기 적용 및 제대 동 맥 및 제대 정맥 내 카테터를 삽입 하였고, 흥부엑스레이를 통해 제 대동맥관 및 제대정맥관의 끝이 적절한 곳에 위치한 것을 확인하였 다. 신생아 출혈 질환을 방지하기 위해 비타민 K1 $0.3 \mathrm{mg}$ 을 정맥 주 사하였고, 예방적 항생제로 ampicillin과 cefotaxime을 투여하였다. 출생 당시 시행한 검사에서 혈색소 $11.7 \mathrm{~g} / \mathrm{dL}$, 백혈구 $5,560 / \mathrm{mm}^{3}$, 혈 소판은 $195,000 / \mathrm{mm}^{3}, \mathrm{C}$-반응단백은 $<1.5 \mathrm{mg} / \mathrm{L}$ 로 확인되었다.

입원 4일째 제대정맥관을 제거하였고 오른쪽 상완정맥에 경피 중 심정맥도관을 삽입하였다. 같은 날 오후 4시 30분경 제대동맥관 역 시 제거하고 알렌 검사를 시행하여 우회순환에 이상이 없음을 확인 한 후 왼쪽 요골동맥에 말초 동맥 카테터를 삽입하였다. 말초 동맥 카테터 삽입 당시 혈압은 승압제 사용 없이 $50 / 30 \mathrm{mmHg}$ (평균 동 맥압 $40 \mathrm{mmHg}$ )로 유지 하였으며, 맥박은 160 회/분, 산소 포화도는 $97 \%$, 소변량은 $3 \mathrm{cc} / \mathrm{kg} / \mathrm{hr}$ 로 안정적으로 활력 징후를 유지하고 있었 다. 그러나 말초 동맥 카테터 삽관 즉시 환자의 왼쪽 손바닥을 포함 한 손가락 전체부분이 창백해지는 양상 보여 바로 말초 동맥 카테터 를 제거한 뒤 왼쪽 팔을 체간보다 높게 올려 놓고, 반대쪽 팔에 따뜻

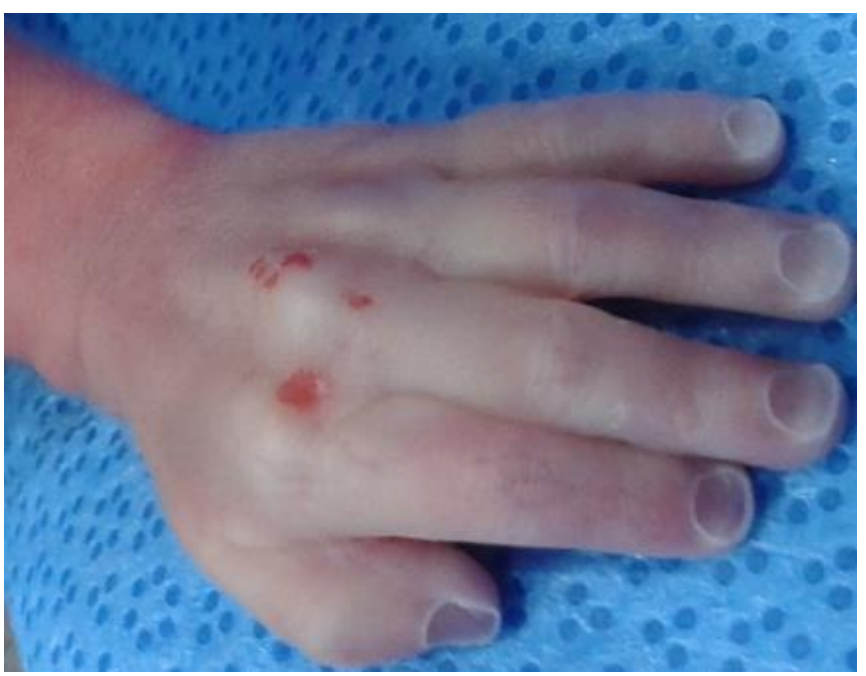

Figure 1. Left hand area pale and then turned blue.
한 물 주머니를 대주어 반사적 혈관 확장을 유도하며 경과 관찰하였 다(Figure 1). 이튿날(입원 5일째) 창백한 양상은 호전되었으나 왼쪽 엄지부터 5 번째 손가락까지 손가락의 첫 번째 마디부분이 괴사 양상 을 보였다(Figure 2). 혈전 가능성 배제할 수 없어 관류를 보존하고 추후 절단가능성을 막기 위해 혈전용해치료를 시작하기로 하고 치 료 전 뇌 초음파를 시행하여 심각한 뇌 출혈이 없음을 확인 후 혈전 용해제로 유로키나아제(urokinase) $4,400 \mathrm{U} / \mathrm{kg}$ 를 10 분에 걸쳐 부하 한 후 동일 용량을 12 시간 동안 투여하였다.

입원 7일째 양쪽 팔에서 시행한 도플러 초음파에서 혈전을 의심 할 만한 소견은 없었으며, 혈류는 정상으로 혈전증보다는 혈관수 축 가능성이 더 커보여 혈전 용해 치료는 중단하기로 하였다(Figure 3). 한편, 추가적으로 혈관 수축에 대한 표준 치료에 반응이 없어, 국소적 혈관 확장을 위해 이환된 부위에 국소적으로 nitroglycerin

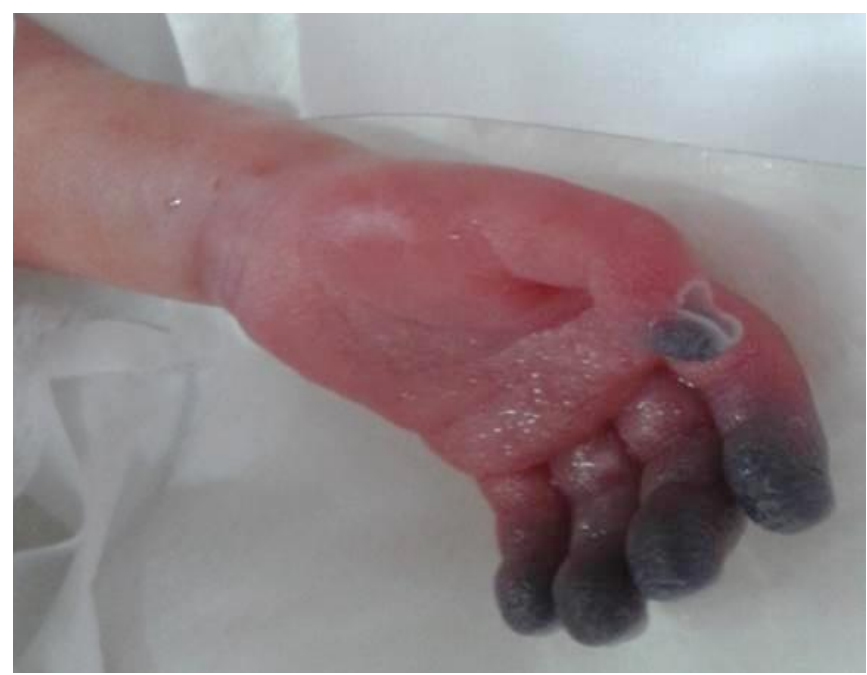

Figure 2. Signs of early necrosis in the finger tips were observed on the 5 day after birth.

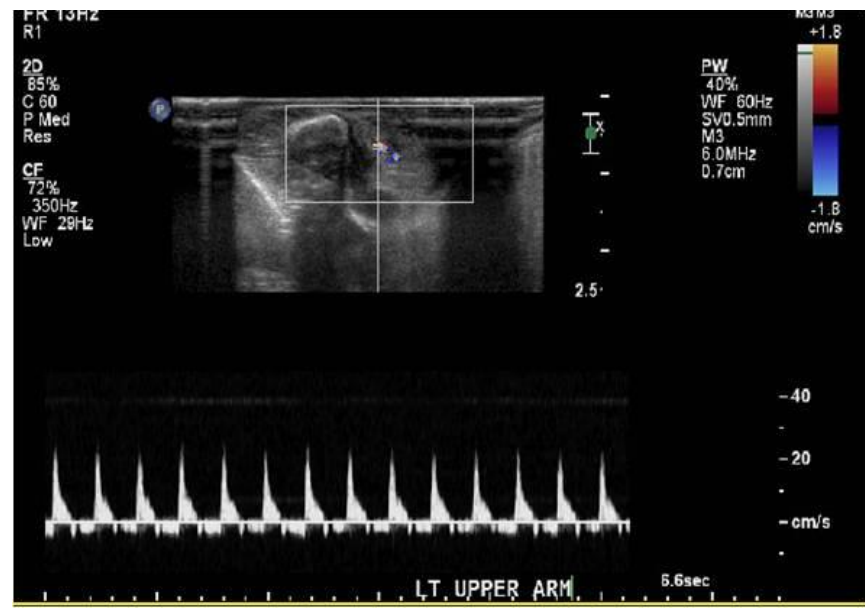

Figure 3. Spectral doppler image showed a normal arterial waveform of the left axillary artery. 
연고(렉토제식연고, $0.2 \%$ glyceryl trinitrate, 제조사 Adamis Phar maceuticals)를 바르며 집중가습치료를 했다. 집중가습치료는 일반 용(LG moisten, H-716CP) 가습기를 사용하였으며, 이환 부위부터 팔꿈치까지 기저귀로 감싸 기저귀 안쪽으로 가습기 관을 연결하여 이환 부위에만 $100 \%$ 의 가습효과를 주는 것으로 이루어졌다(Figure $4 \mathrm{~A}, 4 \mathrm{~B})$. 집중 가습치료 부위의 화상 및 감염을 모니터링하기 위해 이환 부위를 8시간마다 확인하며 치료가 종결될 때까지 매일 24시 간 동안 지속하였다. 환자의 표적 체온은 신생아 정상온도 최고치 인 $37.5^{\circ} \mathrm{C}$ 로 하여 인큐베이터 온도를 조절하였으며, 인큐베이터의 습도는 본원의 미숙아 고습도 공급 프로토콜에 따라 출생 시 $100 \%$

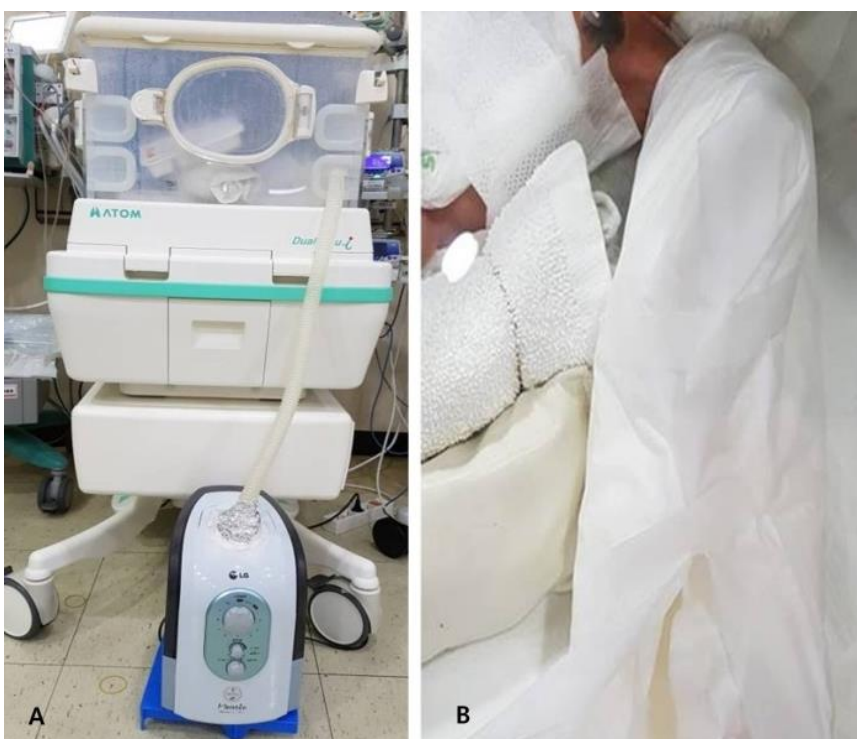

Figure 4. Intensive humidification. (A) Humidifier were pulled out through the line hole of the incubator and fixed. (B) Affected area to the elbow was wrapped in diaper and the humidifier connected to the inside of the diaper.

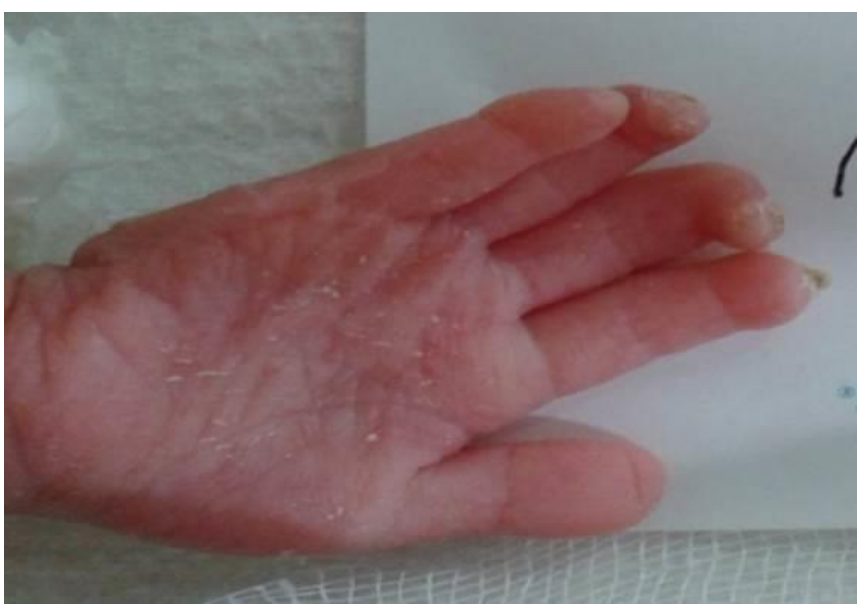

Figure 5. Left hand showed no signs of vascular insufficiency after completion of treatment (36 days).
공급에서 환자의 체중, 피부 상태 및 전해질 수치를 관찰하며 생 후 8일째 60\%까지 줄여 유지하였다. nitroglycerin 연고도포 치료는 nigroglycerin 연고를 허혈 양상이 있는 손가락에서부터 혈관을 따라 왼쪽 손 전체와 팔꿈치까지 8시간마다 발라주었으며, nitroglycerin 으로 인해 발생할 수 있는 저혈압이나 혈관확장에 따른 심박출량 감 소 등을 모니터링하기 위해 활력징후를 매시간 관찰하였으나 부작 용은 없었다.

입원 23 일경 왼쪽 엄지와 2,5 번째 손가락의 색깔과 관류는 호전 되었으나 3, 4 번째 손가락의 끝부분의 괴사부위 남아있어 국소적 nitroglycerin 연고 도포와 집중가습치료를 유지하였고, 입원 31일째 남아있던 4 번째 손가락 끝 마디 $2 \mathrm{~mm}$ 정도의 건성 괴저가 손톱바닥 부분은 유지된 채 탈락되었고, 입원 34 일째 2 번째 손가락 끝 마디 건 성 괴저 $1 \mathrm{~mm}$ 도 호전되었다. 이후 집중가습치료로 인한 국소 피부 손상은 보이지 않았으며, 남은 손가락에도 더 이상 허혈 및 괴사양상 은 관찰되지 않아 입원 36일째 혈관경련수축에 대한 모든 치료를 종 결하였다(Figure 5).

\section{고찰}

신생아 중환자실에서 동맥혈 가스 검사 및 혈압 모니터링을 위한 말초동맥의 경피적 카테터는 많이 이용되고 있으며, 일반적으로 쉽 고 안전하게 시행되지만 경우에 따라 합병증이 발생할 수 있다 ${ }^{2,7,8)}$. 신생아에서 동맥 카테터 삽입에 의해 일시적으로 순환장애가 발생 하는 것은 최대 $73 \%$ 정도인 반면, 영구적으로 허혈 증상이 지속되는 경우는 0-1.6\%로 드문 편이지만, 합병증 발생시 괴사로 인한 병변 부위 절단과 같은 심각한 후유증을 남길 수 있어 주의해야 한다 ${ }^{7)}$.

혈관경련은 보통 몇 분에서 수 시간 내에 혈액순환이 완전히 회복 되고, 허혈 양상이 일시적인 것으로 임상적으로 진단이 가능하나 혈 전 색전증은 혈관 폐색을 진단하기 위한 영상학적 검사의 한계로 조 기진단이 어렵다 ${ }^{9}$. 또한 혈전 색전증이 있다고 모두 증상을 동반하 는 것은 아니어서, 부분적으로 폐쇄되었거나, 우회 순환이 충분한 경우에는 증상이 없거나 일시적일 수 있다. 따라서 신생아중환자실 에서 동맥 카테터를 삽입했을 때 말단부위가 창백해지거나 청색증 이 발생되면 그 원인이 동맥수축에 따른 일시적인 혈관경련인지 또 는 심각한 합병증이 생길 수 있는 혈전증의 초기증상인지 구분하기 어렵기 때문에 의심이 되는 경우에는 도플러 초음파를 시행해야 하 며, 혈전증의 경우에는 급속한 괴사로 진행할 수 있어 적절한 치료 방법과 시기를 선택하여야 한다. 말초 동맥의 혈전증이 의심되는 경 우 치료는 우선 원인이 되는 말초 동맥 카테터나 제대동맥관을 제거 하는 것이며, 동맥 카테터를 제거하였음에도 조직 허혈이 지속된다 면 영구적인 혈관경련이나 원위부 동맥의 혈전가능성을 생각하고 항응고제나 혈전용해제를 사용해야 한다. 고용량의 유로키나아제 
(urokinase), 저분자량 헤파린, 미분획 헤파린과 항트롬빈농축물의 혼합물을 정맥 내 투여할 수 있으며, 이런 약물 치료를 하기 전 뇌출 혈과 같은 심각한 합병증의 가능성은 고려해야 한다 ${ }^{4,10)}$.

말초 동맥의 혈관 경련으로 인한 조직 허혈이 의심되는 경우, 병 변 부위의 카테터를 제거하고, 반대편 부위에 온찜질을 하여 반사적 혈관 확장을 유도하면서 허혈 부위를 심장의 위치보다 높게 유지하 는 표준 치료를 시행한다. 표준 치료에 반응하지 않는 경우, 성인에 서는 항응고 및 혈관 확장제를 사용하거나 수술로 혈전을 제거하기 도 하나 ${ }^{11)}$, 신생아에서 적용된 사례가 없어 치료에 어려움이 있다. 그러나 최근 몇몇 증례보고를 통해 신생아에서 조직허혈 병변에 국 소용 nitroglycerin 연고를 도포하여 괴사로의 진행을 예방하는 효과 가 입증된 바 있으며 ${ }^{4,12,13)}$, 그 기전은 nitroglycerin이 유기질산염으 로 산화질소를 생성하여 혈관의 평활근을 이완시키고 혈관을 확장 시킬 뿐 아니라 말초 허혈 부위로의 측부 순환을 증가시켜 허혈을 호 전시키는 것이다. 이환 부위에 도달하는 nitroglycerin의 양은 연고 의 양과 바르는 면적에 따라 다양하며, 초기용량은 $4 \mathrm{~mm} / \mathrm{kg}(1.22$ $\mathrm{mg} / \mathrm{kg}$ )로 사용하고 1시간 내에 발현되어 6시간 정도 지속된다 ${ }^{5)}$. 미 숙아의 경우 미숙한 피부장벽으로 인해 약물흡수가 잘되어 전신적 인 합병증이 발생할 위험성이 있다 보고된 바 있으나 아직까지 신생 아에서 국소 nitroglycerin 연고의 사용으로 합병증이 발생한 경우는 없으며 본 증례에서도 저혈압과 빈맥과 같은 합병증을 모니터링 하 였으나 발생되지 않았다.

Samiee-Zafarghandy 등 ${ }^{4)}$ 이 국소 nitroglycerin 연고도포에 대하 여 보고한 증례보고에 따르면 총 15 명 중 2 명을 제외한 모든 증례 에서 완전한 회복을 보였으며, 한 명은 왼쪽 엄지발가락 끝부분이, 다른 한 명은 왼쪽 2,3 번째 발가락부분이 조직 괴사로 인한 절단을 보였다. 조직 허혈이 광범위 할수록, 괴사의 정도가 심할수록 절단 의 위험도가 높아지는 것으로 미루어볼 때, 증상이 심할 경우 국소 nitroglycerin 연고 도포 외 추가적인 치료가 더 필요할 것으로 생각 된다.

Winter $^{14)}$ 가 1960년대 이후 상처치료에 있어 습한 환경의 중요성 을 강조한 이래로 그 기전과 치료효과에 대한 연구가 지속되었다. 가습치료는 상처표면이 건조해지는 것을 막아 표피세포가 쉽게 이 동되어 케라틴 세포의 증식 및 섬유 모세포의 성장을 자극하여 상피 화가 빠르게 진행 될 뿐 아니라 단백질 분해효소의 작용으로 죽은 조 직과 섬유소의 분해가 증가되어 상처치유에 도움이 된다 ${ }^{15)}$. Reish 등 ${ }^{16)}$ 의 연구에서 보면, 무균 조건 하에서 상처주위의 환경이 건조할 때 보다는 습할 때 상처부위의 염증이 크게 감소되었으며, 흥터의 표면 적이 현저히 작은 것을 알 수 있었다. 이 기전을 토대로 성인에서는 하이드로콜로이드(hydrocolloid) 제제를 사용한 습윤드레싱 등이 조직 허혈에 의한 말초조직 괴사 치료에 이용되고 있다 ${ }^{17)}$. 그러나 신 생아, 특히 초극소 미숙아의 경우 손가락 등의 말초조직에 습윤드레 싱을 적용하기에 어려움이 있어 본원에서는 병변 부위에 집중가습
치료를 적용하게 되었다.

초극소 미숙아에서 고농도의 가습 환경이 진균 감염 등의 위험을 증가시키는 것으로 보고되고 있어 ${ }^{18)}$, 병변 외 다른 부위가 가습이 되 지 않도록 병변을 포함한 말단부위만을 감싸 병변 부위에만 가습이 되도록 하였다. 가습의 온도는 신생아 정상 온도의 최고치인 $37.5^{\circ} \mathrm{C}$ 로 하여 병변 내 혈관확장을 유도하였다. 집중가습치료 기간 동안 감염 및 고온에 의한 화상을 모니터링하기 위해 8시간 마다 병변 부 위를 확인하였으나, 감염 및 화상 등의 부작용은 나타나지 않았다.

결론적으로, 극소 저체중 출생아에서 말초 동맥 카테터 삽입 에 따른 조직 허혈 발생 후 심각한 조직 괴사가 발생하였으나 국소 nitroglycerin 연고의 사용과 집중가습치료를 병행하여 심한 합병증 없이 호전된 경험을 보고하는 바이다. 집중가습치료의 효과에 대하 여는 추가적인 연구가 필요할 것으로 사료되나, 보존적 치료에 반응 하지 않는 말초 동맥 카테터에 의해 발생하는 2 차적 조직 허혈의 치 료에 nitroglycerin 연고도포가 안전하게 사용될 수 있으며, 가습치료 를 병용할 시 피부의 상피화를 촉진시키고 흥터의 형성을 감소시켜 환자의 치료효과를 극대화 시킬 수 있어 보고하는 바이다.

\section{REFERENCES}

1) Arshad A, McCarthy MJ. Management of limb ischaemia in the neonate and infant. Eur J Vasc Endovasc Surg 2009;38:61-5.

2) Schindler E, Kowald B, Suess H, Niehaus-Borquez B, Tausch $\mathrm{B}$, Brecher A. Catheterization of the radial or brachial artery in neonates and infants. Paediatr Anaesth 2005;15:677-82.

3) Cartwright GW, Schreiner RL. Major complication secondary to percutaneous radial artery catheterization in the neonate. Pediatrics 1980;65:139-41.

4) Samiee-Zafarghandy S, van den Anker JN, Ben Fadel N. Topical nitroglycerin in neonates with tissue injury: a case report and review of the literature. Paediatr Child Health 2014;19:9-12.

5) Mosalli R, Elbaz M, Paes B. Topical nitroglycerine for neonatal arterial associated peripheral ischemia following cannulation: a case report and comprehensive literature review. Case Rep Pediatr 2013:608516.

6) Kim DH. Neonatal thromboembolic disorders. J Korean Soc Neonatol 2011;18:23-33.

7) Todres ID, Rogers MC, Shannon DC, Moylan FM, Ryan JF. Percutaneous catheterization of the radial artery in the critically ill neonate. J Pediatr 1975;87:273-5.

8) Hack WW, Vos A, Okken A. Incidence of forearm and hand ischaemia related to radial artery cannulation in newborn infants. Intensive Care Med 1990;16:50-3.

9) Will A. Neonatal haemostasis and the management of neonatal thrombosis. Br J Haematol 2015;169:324-32. 
10) Saxonhouse MA. Management of neonatal thrombosis. Clin Perinatol 2012;39:191-208.

11) Valentine RJ, Modrall JG, Clagett GP. Hand ischemia after radial artery cannulation. J Am Coll Surg 2005;201:18-22.

12) Baserga MC, Puri A, Sola A. The use of topical nitroglycerin ointment to treat peripheral tissue ischemia secondary to arterial line complications in neonates. J Perinatol 2002;22:416-9.

13) Guran P, Beal G, Brion N, Advenier C. Topical nitroglycerin as an aid to insertion of peripheral venous catheters in neonates. $\mathrm{J}$ Pediatr 1989;115:1025.

14) Winter GD. Formation of the scab and the rate of epithelization of superficial wounds in the skin of the young domestic pig.
Nature 1962;193:293-4.

15) Eaglstein WH. Moist wound healing with occlusive dressings: a clinical focus. Dermatol Surg 2001;27:175-81.

16) Reish RG, Zuhaili B, Bergmann J, Aflaki P, Koyama T, Hackl F, et al. Modulation of scarring in a liquid environment in the Yorkshire pig. Wound Repair Regen 2009;17:806-16.

17) Field FK, Kerstein MD. Overview of wound healing in a moist environment. Am J Surg 1994;167:2-6.

18) Sinclair L, Crisp J, Sinn J. Variability in incubator humidity practices in the management of preterm infants. J Paediatr Child Health 2009;45:535-40. 